\title{
Basic unit size in the analysis of the distribution of spatial landscape elements on the basis of the lithostratigraphic geodiversity of the Ojców National Park (Poland)
}

\author{
Tomasz Bartuś \\ AGH University of Science and Technology, Faculty of Geology, Geophysics and Environmental Protection, Department \\ of the General Geology and Geotourism; al. A. Mickiewicza 30, 30-059 Krakow, Poland; e-mail: bartus@uci.agh.edu.pl
}

(C) 2017 Authors. This is an open access publication, which can be used, distributed and reproduced in any medium according to the Creative Commons CC-BY 4.0 License requiring that the original work has been properly cited.

Received: 19.10.2016; accepted: 30.06.2017

\begin{abstract}
Spatial analyses of landscape element diversity are always carried out on the basis of a previously established analytical grid. It divides the research area into ' $n$ ' smaller areas - basic units before calculating various landscape measures for each of them. The selection of an appropriate analytical grid, particularly its cell size, is a key issue for the results obtained and conclusions drawn from them. The article describes the procedure of empirical selection of a basic unit size in the medium-scale landscape and geodiversity analyses employing a regular analytical grid with square cells. The established methodology was based on observations of the distribution of the number of studied feature categories in the analytical grid fields. The correctness measures for the selection of the optimal basic unit size were the distributions themselves, as well as selected descriptive statistical parameters. The conducted analyses accurately illustrate the dependences between the variable size of the basic unit size and the number of the studied feature categories. The research conducted proves that the simple empirical approximation of the optimal basic unit size is possible.

The proposed procedure allowed the determination of the optimal basic unit size for the variation of the lithostratigraphic units of the Ojców National Park. The optimal unit size for the accuracy data typical for a reference scale 1:50 000 was specified as $500 \mathrm{~m}$.
\end{abstract}

Keywords: basic unit size estimation; landscape; geodiversity, lithostratigraphic geodiversity, Shannon diversity index, Ojców National Park

\section{INTRODUCTION}

Everyone intuitively feels what belongs under the notion of landscape. In the ordinary sense, this term is generally a synonym of the view that we see at a given time. In actual fact, landscape is an ambiguous term and is frequently defined in a different way (Zonneveld 1995). In general, it is understood as a set of natural and anthropological characteristics distinguishing an area and assisting in its description.
Towards the end of the last century, the term landscape began to be combined with biodiversity derived from the ecological sciences (Gaston 1996, Abe et al. 1997). In the wake of this change, the circle of geologists, geomorphologists and geographers forged the term of geodiversity (Sharples 1993, Gray 2004). This extraordinarily broad-ranging issue was initially associated with the nature conservation context. With time, many other meanings were also attached to it (Prosser 2002, Stanley 2003, Kozłowski 2004). 
An analytical approach is most often used in the research on geodiversity and this methodology defines the final evaluation as the sum of partial factors: the variety of geology, landforms, soil cover, climate, and the interactions between them (Sharples 1993, Dixon 1996, Eberhard 1997, Leser \& Nagel 1998, Stanley 2001, Serrano \& Ruiz-Flaño 2007a, 2007b). Each of the listed components is described by a number of detailed criteria, for example geological diversity - by a variability of the lithographic and stratigraphic units, tectonics structures, presence of geosites and others. The assessment of the diversity is based on the determination of the value of relevant landscape metrics (McGarigal \& Marks 1995, Gray 2004, McGarigal et al. 2012). The concept is derived from the biogeographical theory of islands (McArthur \& Wilson 1968) and is based on the observation that each landscape can be reduced to a mosaic of disjoint elements called patches and the corridors connected to them that occur in a certain matrix (Forman \& Godron 1986). They create characteristic landscape patterns in which similar elements occur in different places of the space (Forman 1997). The described structures are the essential source of information in ecological research and, in particular, in bio- and geodiversity assessments. The pioneers of the use of landscape metrics in the study of the abiotic nature diversity were Burnett et al. (1998) and Nichols et al. (1998).

The researching of detailed criteria is typically performed on the basis of the adopted artificial analytical grid whose borders are not reflected by the natural environment components in any way. It divides the research area into the ' $n$ ' smaller areas basic units. In most typical situations, cells of analytical grids have a shape of geometrically fitting squares, less often of other plane figures. As Kot \& Leśniak (2006) aptly noticed, the most considerable merits of such analytical grids are the clarity of their structure and adaptation. However, in most cases, their most serious flaw is the random distribution in space and their severing of natural borders.

Correct analytical grid selection is a difficult issue depending on many factors. Apart from raster analysis problems (Wu 2004, Hengl 2006, Buyantuyev \& Wu 2007), focusing exclusively on vector research, factors described in the literature as having the greatest effect on the proper basic unit size selection include: scale of input cartographic materials and resulting from it mapping accuracy of the analysed objects and their characteristics, the minimum, average and maximum features size of an analysed environment component (scale theory), the spatial variability of studied feature, purpose of a study and resulting from it mapping accuracy and scale of the resulting materials (Turner et al. 1989, Gergel \& Turner 2002, Corry \& Lafortezza 2007).

The methodology of selecting basic unit size is quite rich. In spatial research, the problem is known as the "modifiable areal unit problem (MAUP)". It was recognized in the early 1930's by Gehlke \& Biehl (1934). The authors, when analyzing census results, observed inconsistent correlation coefficients between pairs of attributes observed in census blocks in different census scales. This problem was described in detail by Openshaw (1984). One of the most popular tools used to determine spatial scales is the semivariogram method (Matheron 1963). It connects the analytical grid size from the radius of the autocorrelation of regionalized variables (Rossi et al 1992, Meisel \& Turner 1998, Radeloff et al. 2000, Suchożebrski 2004). There are also a number of other spatial scale analysis methods, for example: lacunarity analysis (Plotnick et al. 1993, Plotnick et al. 1996), spectral analysis (Legendre \& Fortin 1989), paired quadrat variance methods (PQV, Greig-Smith 1983) and a variety of fractal methods (Krummel et al. 1987). Regardless of the existing methods, the authors in their landscape studies, a priori accepted typical cell sizes of the grids known from the literature (Tab. 1).

To date, science has not worked out a single general procedure suitable for all cases. The described methods require complicated mathematical formulas and specialized software. An interesting approach to the selection of the optimum basic unit size was presented in the report of the European Commission entitled From land cover to landscape diversity in the European Union (Eiden et al. 2000). In this document, concerning geodiversity research and resulting from a cooperation between various offices of the European Commission (DG AGRI ${ }^{1}$, EUROSTAT ${ }^{2}, \mathrm{JRC}^{3}$, and $\mathrm{EEA}^{4}$ ), the dependence of

\footnotetext{
DG AGRI - Agriculture and Rurar Development.

EUROSTT - European Statistical Office.

JRC - Joint Research Centre.

EEA - European Envinronment Agency.
} 
the basic unit size on a number of analysed feature categories in successive analytical grid cells was demonstrated. The proposed method uses data in the vector model and in surface geometry. It can be used for any extent and any accuracy of mapped objects. It does not require specialized software and is easy to use yet it has not been widely done so. Considering the high number of publications in which researchers use the arbitrary cells sizes of analytical grids, it will be an attractive alternative to quite complicated geostatistical or fractal methods. The presented analysis is an attempt to use it in medium-scale geodiversity studies.

The aim of the study was to determine the optimal basic unit size in the lithostratigraphic diversity analysis in the area of the Ojców National Park (ONP, southern Poland). The ONP area has landscape characteristics typical for karstland areas, with the existing relief mainly an effect of the varied susceptibility of the rocks to erosion. Therefore, the variability of the lithostratigraphic units is crucial for determining the landscape values of the ONP area. The main components of the landscape are the surface of the Ojców plateau, which is covered by Pleistocene loesses and crowned with huge Upper Jurassic massive limestone tors called monadnocks (S.W. Alexandrowicz \& Z. Alexandrowicz 2003). Among the groups of monadnocks are Paleogene waste clays with limestone and chert rubbles and eluvium clays with cherts, which are a residuum after weathering and erosion of the bedded limestones. The upland surface is dissected by numerous valleys and gorges. The central part of the analyzed area is occupied by the Prądnik Valley, which cuts deep scarps to a depth of about $100 \mathrm{~m}$ into the Ojców plateau. In the steep slopes of the valleys and walls of the gorges, the Upper Jurassic bedded limestone with cherts and massive limestones is exposed. Along the valleys, Holocene sands, gravels and silts, clays and stripes (alluvial soils) of flood terrace and muds are all to be seen.

Table 1

Basic unite size in selected landscape studies

\begin{tabular}{|l|l|c|c|}
\hline \multicolumn{1}{|c|}{ Authors } & \multicolumn{1}{|c|}{ Basic unit size } & Surface area $\left[\mathbf{k m}^{2}\right]$ & Reference data scale \\
\hline Kozieł (1993) & $100 \times 100 \mathrm{~m}$ & 0.01 & $1: 10000$ \\
\hline \multirow{3}{*}{ Kot (2014) } & \multirow{3}{*}{$500 \times 500 \mathrm{~m}$} & 279.7 & $1: 25000$ \\
\cline { 3 - 4 } & & 26.7 & $1: 25000$ \\
\cline { 3 - 4 } & & 10.0 & $1: 10000$, \\
& & 285.25000 \\
\hline Hjort \& Luoto (2010) & $500 \times 500 \mathrm{~m}$ & 44 & $1: 20000-1: 400000$ \\
\hline Örsi (2011) & $500 \times 500 \mathrm{~m}$ & $\sim 400$ & $1: 10000-1: 100000$ \\
\hline Miśkiewicz (2009) & $1.0 \times 1.0 \mathrm{~km}$ & $\sim 180$ & $1: 50000$ \\
\hline Quinta-Nova \& Cabaceira (2014) & $10.0 \times 10.0 \mathrm{~km}$ & $\sim 79000$ & $1: 25000$ \\
\hline Š́mová \& Gdulová (2011) & $12.5 \times 12.5 \mathrm{~km}$ & $\sim 511000$ & unknown \\
\hline Silva et al. (2013) & $13.8 \times 13.8 \mathrm{~km}$ & $\sim 200000$ & unknown \\
\hline Pereira et al. (2013) & $25 \times 25 \mathrm{~km}$ & & \\
\hline
\end{tabular}

\section{METHODS}

Let us assume that the research area covers ca. $50 \mathrm{~km}^{2}$, and the studied issue is the spatial diversity of lithostratigraphic units, the analysed feature is present in 9 categories and their distribution in the studied area is uniform. When we adapt a relatively large size of a basic unit (e.g.: $5 \mathrm{~km}^{2}$ ), the probability that each basic unit will contain a full, maximum number of studied feature categories is very high (Fig. 1 - a). Individual basic units will be characterised by a maximum internal diversity. The resulting cartogram based on calculations will display the same maximum diversity value in almost each cell of the developed grid, and thus, it will not have any analytical value. However, when the basic unit size is restricted to the minimum size of the object being studied (e.g. the area of the smallest lithostratigraphic unit) or smaller, it can be expected that each analytical grid cell will be 
characterised by a minimal internal diversity. This is possible because each basic unit of the analytical cell contains one or, at most, a few categories of the studied feature (Fig. $1-$ b). The generated cartogram will display the same minimal diversity value in almost each cell of the developed grid. Slightly higher diversity values will indicate solely the basic units located along the variability limits of the studied feature categories. As it can be seen, in this case the map will not reveal a sufficient diversity as well, and therefore, it will also not contribute any substantial value.

Both cases present extreme situations but they illustrate the discussed issue fairly well. The optimal basic unit size is a compromise between the described extreme situations and can be approximated by empirical research. The analysis requires a number of experiments to be performed using various basic unit sizes. For each experiment, a minimum and maximum number of studied feature categories must be calculated and then presented in the same chart. The individual combination of minimum and maximum values plots the curve (Fig. 1). As G. Eiden et al. (2000) suggests, we have the optimal basic unit size when the gap between a minimum and maximum number of the studied feature categories is the largest. In the discussed situation, the smallest number of analytical grid fields is characterised by the minimum and the maximum diversity of studied feature categories, and the maximum number of fields is characterized by the average diversity.

The ONP area consists of two larger sub-areas: northern (in the Pieskowa Skała region) and southern (in the Ojców region) linked by a narrow pass of the Prądnik Valley, as well as of four little ONP enclaves: two located in the west of the park, in the Pieskowa Skała and Sąspów regions, and two situated in the east, in the Cianowice Małe region (Fig. 2). The research concerned the surface variability of lithostratigraphic units. The geological map of the Ojców National Park, together with the transition zone at the scale of 1:50 000, drawn up in 1997 (Płonczyński 2001), was the source material for the data used in the research (Fig. 2). The criterion of the separation of the lithostratigraphic units were lithological variation and age of the geological deposits. Due to the lack of relevant data, different resolutions of the separated categories were used for different geochronological units. For the Jurassic and Paleogene deposits it was a stage and for the Quaternary - an epoch.

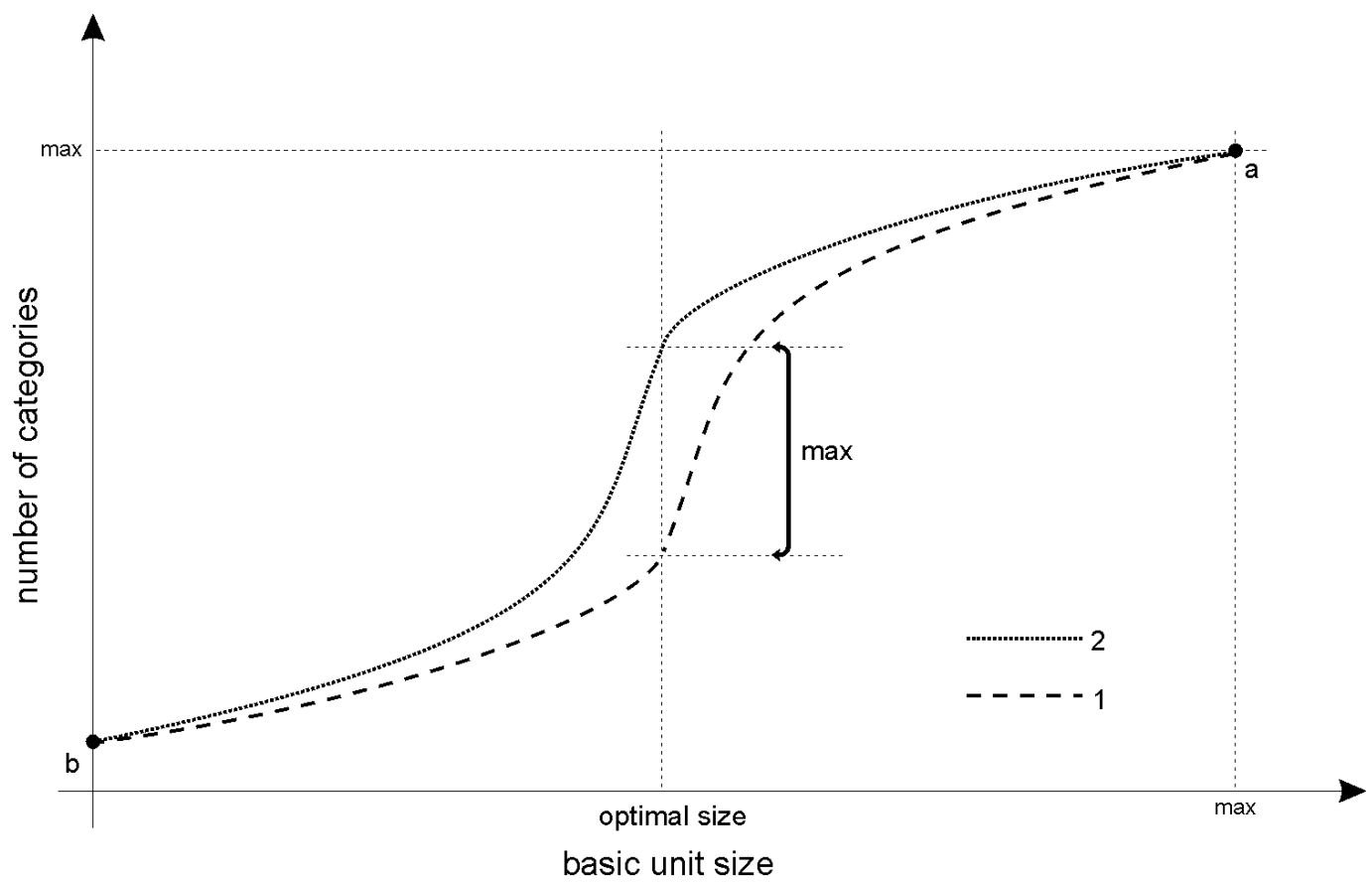

Fig. 1. Relationship between the size of the grid cells and the number of the categories of studied feature: 1 - line of the minimum number of categories in basic units, 2 - a line of the maximum number of categories in basic units, a-maximum diversity point, $b$ - minimum diversity point (based on Eiden et al. 2000) 


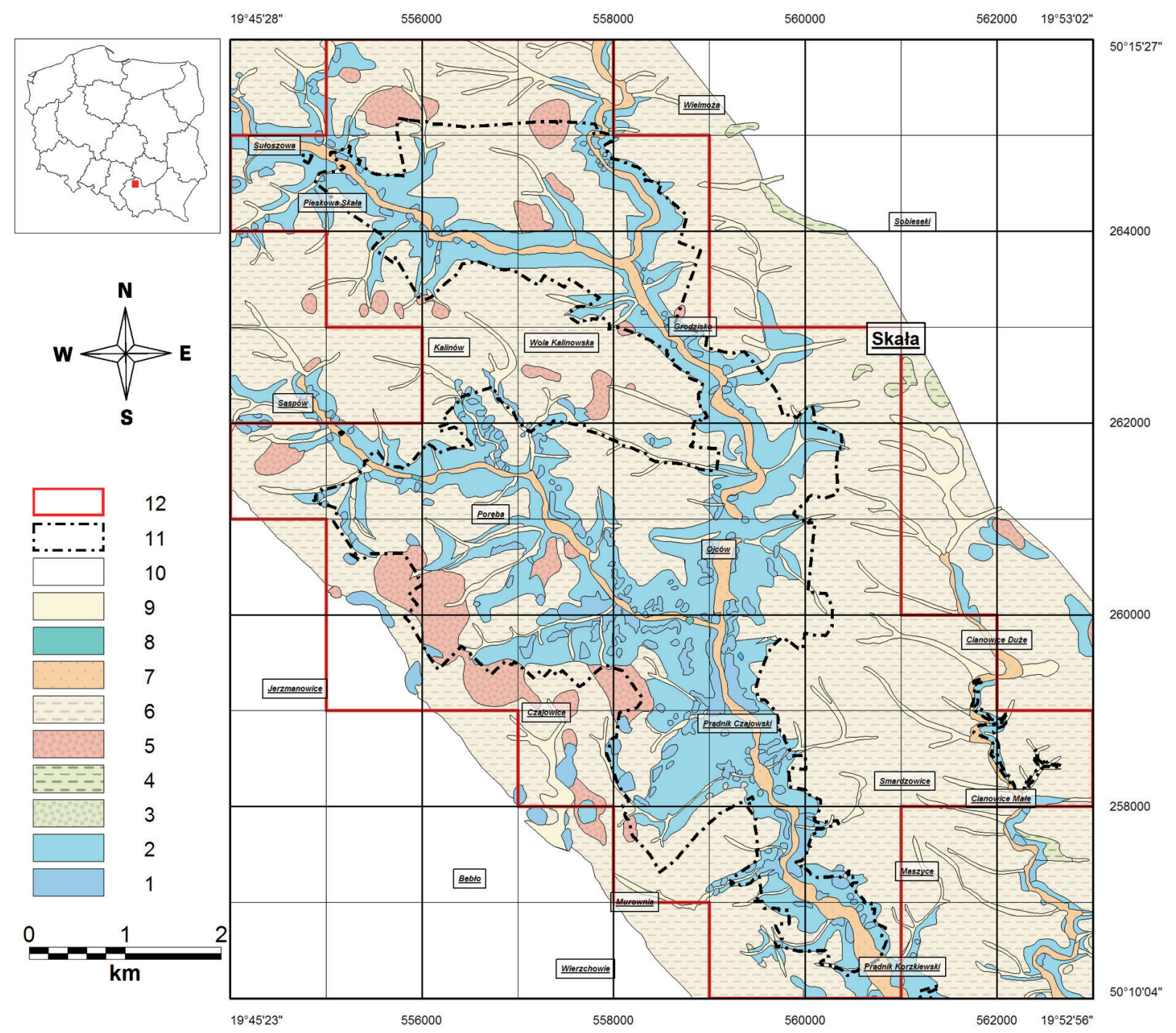

Fig. 2. Geological map of the Ojców National Park. Late Jurassic period: 1 - massive limestones; 2 - bedded limestone with cherts; Late Cretaceous: 3 - conglomerates, in places calcareous sandstones and sands; 4 - bedrocks with cherts, marl limestones and marls; Paleogene: 5 - chert rubbles and eluvium clays with cherts; Pleistocene: 6 - loesses; Holocene: 7 - sands, gravels and silts, clays and stripes (alluvial soils) of flood terraces; 8 - travertine; 9 - valley bottom mud; 10 - area outside of the ONP buffer zone; 11 - ONP boundaries; 12 - research area (based on Płonczyński 2001)

The vector geological map encompassed the geological units within 9 lithostratigraphic units (Tab. 2). The study area was selected so that it could cover the entire OPN area. Due to the partial lack of the data in the part of the basic units located in the southwest part of the analysed area, the results of the geodiversity analyses carried out for these cells should be treated with a certain degree of suspicion.

In the analyses, artificial and regular grids with square cells and the most known in the literature were employed, namely cell sizes of $500 \mathrm{~m}$ and $1000 \mathrm{~m}$. Additionally, for comparative purposes, were defined grids with cells: $100 \mathrm{~m}, 200 \mathrm{~m}$ and $250 \mathrm{~m}$. Grids locations were oriented to the grid of the '1992' geodetic coordinate system.

The number of the lithostratigraphic unit categories for each analytical grid cell was determined for all basic unit sizes. The determined values underwent simple statistical descriptive analyses.

Distribution histograms for the number of categories in basic units were analysed for each determined analytical grids. In correctly selected 
analytical grids, the analysed environmental component distributions, calculated for individual basic units should be Normal. The statistical descriptive analysis of the charts allowed the selection of an analytical grid with the potentially optimal basic unit size.

Table 2

Area and number of lithostratigraphic units in the research area

\begin{tabular}{|c|c|c|}
\hline \multirow{2}{*}{ Code $^{*}$} & Area & $\begin{array}{c}\text { Number of } \\
\text { patches }\end{array}$ \\
\cline { 2 - 3 } & {$\left[\mathbf{k m}^{2}\right]$} & {$[-]$} \\
\hline 1 & 2.1 & 204 \\
\hline 2 & 10.4 & 86 \\
\hline 3 & 0.003 & 1 \\
\hline 4 & 0.04 & 3 \\
\hline 5 & 2.4 & 25 \\
\hline 6 & 27.5 & 16 \\
\hline 7 & 2.02 & 6 \\
\hline 8 & 0.01 & 2 \\
\hline 9 & 2.6 & 67 \\
\hline$\Sigma$ & 47 & 410 \\
\hline
\end{tabular}

* Lithostratigraphic codes as in Figure 2.

Regardless of the selection made, the diversity analysis of lithostratigraphic units present was conducted for each adopted analytical grid variant. The research was an attempt at the verification of the conclusions resulting from the initial diversity analyses of the number of categories in the analytical grid basic units. The Shannon's diversity index (SHDI) was applied as the geological structure diversity measure (Equations (1) and (2); Shannon \& Weaver 1949). It is one of the best known landscape metrics, an absolute index which enables comparisons with other spatial extents and analysed criteria. Due to this, it is widely used in geodiversity research. SHDI measures proportional distribution of the studied feature among the categories. The value of the parameter increases with the increase of the number of categories and the increase of the degree of uniform coverage of the unit area by different categories. The parameter attains a value of " 0 " when only one category of the feature is present in the analysed unit:
$S H D I=-\sum_{i=1}^{n} p_{i} \cdot \ln p_{i}$

where:

$n$-number of categories of the studied feature,

$p_{i}$-probability of $i^{\text {th }}$ feature occurrence.

$p_{i}=\frac{S_{i}}{S_{p}} \cdot 100 \%$

where:

$S_{i}$-area covered by $i^{\text {th }}$ category of the studied feature,

$S_{p}$-basic unit area.

In the research, Geomedia Professional (6.1.6.19) was used.

\section{RESULTS AND DISCUSSION}

The analysis of the average number of categories indicates a gradual increase of the statistical parameters value, as the basic unit size increases (Tab. 3). For a grid with the smallest cell size (with a size of $100 \mathrm{~m}$ ), only one lithostratigraphic unit can be observed in $41 \%$ of the basic units, while in over $80 \%$ of these basic units, there are either one or two lithostratigraphic units. The average number of the categories increases from $<2$ (for the grid with a basic unit size of $100 \mathrm{~m}$ ) to 5 (for $1000 \mathrm{~m}$ ). There is a clear tendency for the increase in the modal number of categories with the increase in the grid cell size. The detailed research revealed that its nature resembled the exponential one. The maximum number of categories in the analytical grids grows from 5 (for the grid with a basic unit size of $100 \mathrm{~m}$ ) to 7 (for $1000 \mathrm{~m}$ ).

After the so-called outlying values are rejected, it appears that the analytical grids with a basic unit size of $100-250 \mathrm{~m}$ are characterized by little ranges between the maximum and minimum number of categories occurring in them (intervals include 2-3 categories) and considerably smaller quartile ranges, $Q_{25 \%}-Q_{75 \%}$ in all three grids containing an interval of only one category (Fig. 3). The grids with a basic unit size of $500 \mathrm{~m}$ and $1000 \mathrm{~m}$ were characterised by relatively larger ranges between the maximum and the minimum category numbers, as well as by twice as large ranges for the same quartiles. No outlying category numbers in the cells of these grids indicate more even distributions in individual basic units (Fig. 3). 
Table 3

Descriptive statistics of the lithostratigraphic units categories in the analytical grids with various basic unit sizes

\begin{tabular}{|c|c|c|c|c|c|c|c|c|c|}
\hline $\begin{array}{c}\text { Basic } \\
\text { unit size } \\
{[\mathbf{m}]}\end{array}$ & $\begin{array}{c}\text { Number } \\
\text { of basic } \\
\text { units }\end{array}$ & Mean & Median & Mode & $\begin{array}{c}\text { Mode } \\
\text { multi- } \\
\text { plicity }\end{array}$ & Min & Max & Skewness & Kurtosis \\
\hline 100 & 4800 & 1.82 & 2 & 1 & 1961 & 1 & 5 & 0.64 & -0.36 \\
\hline 200 & 1200 & 2.43 & 2 & 2 & 387 & 1 & 5 & 0.25 & -0.70 \\
\hline 250 & 769 & 2.69 & 3 & 3 & 245 & 1 & 6 & 0.18 & -0.57 \\
\hline 500 & 192 & 3.74 & 4 & 4 & 71 & 1 & 6 & -0.27 & -0.54 \\
\hline 1000 & 48 & 4.94 & 5 & 5 & 21 & 2 & 7 & -0.54 & 0.41 \\
\hline
\end{tabular}

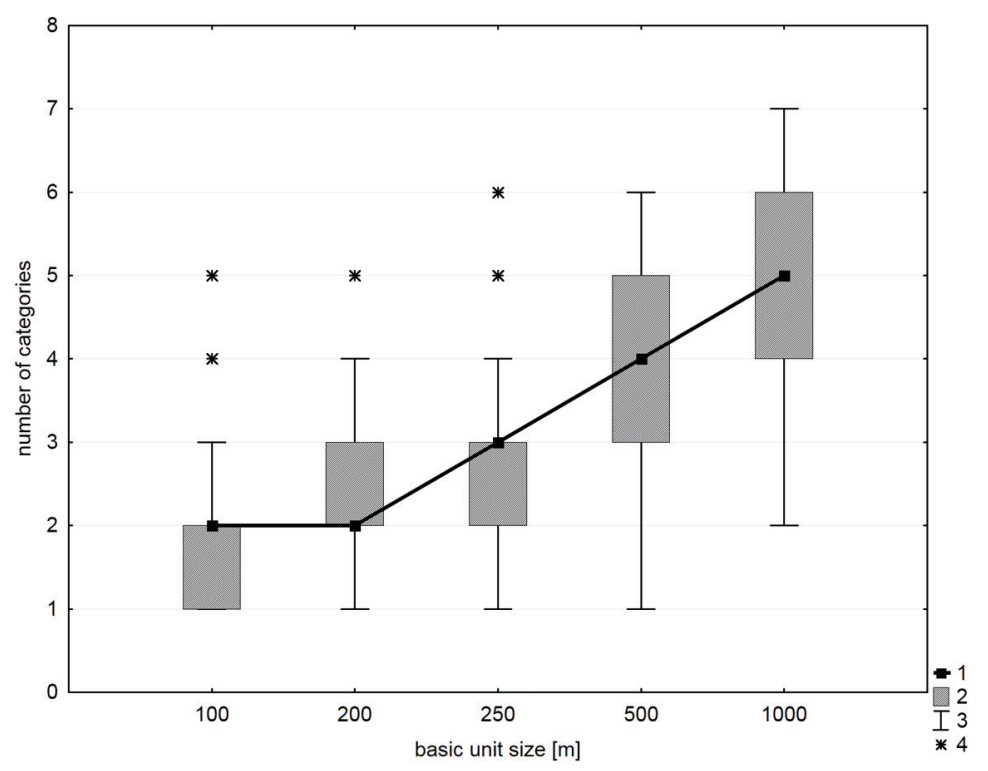

Fig. 3. Median value (1), $Q_{25 \%}-Q_{75 \%}$ quartiles (2), non-outlying interval (3) and outlying category numbers (4) plotted for analytical grids with various basic unit size

The initial distributions analysis already allowed the classification of them as one of two types: asymmetrical to the right (Tab. 3, Fig. 4A-C) and asymmetrical to the left -resembling the normal distribution (Tab. 3, Fig. 4D, E). Analyses of the conformity of empirical distributions with the normal distribution conducted using the $\chi^{2}$ test did not allow for the adaptation of the zero hypotheses at the assumed significance level of 0.05 (Fig. 4). The domination of the modal values (usually consisting of two adjoining categories) is visible in all charts asymmetrical to the right. The domination of the analytical grid cells with one, two or three lithostratigraphic units is clearly visible in all three charts (for the basic unit size of 100-250 m). The modal class is very clearly emphasized in the charts plotted for the analytical grids with the basic unit size of 500 and $1000 \mathrm{~m}$ (Fig. 4D, E). In the case of the 500-metre grid, the modal number of categories in the basic units is 4 . It covers $37 \%$ of all observations (Tab. 3, Fig. 4D). In the case of the 1000-metre grid, the modal number of categories is larger by one unit and amounts to 5. It means that it includes as many as $43 \%$ of all observations (Tab. 3, Fig. 4E).

On the basis of the conducted analyses it can be said that the analytical grids with the sizes of $100-250 \mathrm{~m}$ should be rejected as providing too little information. They indicate this by means of the distributions which are visibly asymmetrical to the right, manifested in the dominance of one or two categories in the analytical grid basic units, very narrow ranges between the minimum and maximum values for the number of categories, as well as due to the first and the third quartile values. The grids with the sizes of $500 \mathrm{~m}$ and $1000 \mathrm{~m}$ were characterized by a gap between the minimum and maximum numbers of categories in the basic units and the quartile ranges which 
was almost twice as large. The plotted histograms revealed that both grids were distinguished by distributions resembling the normal one, with the modal intervals clearly emphasised and with a small number of basic units characterised by the minimum and maximum numbers of the studied feature categories. The conducted analyses do
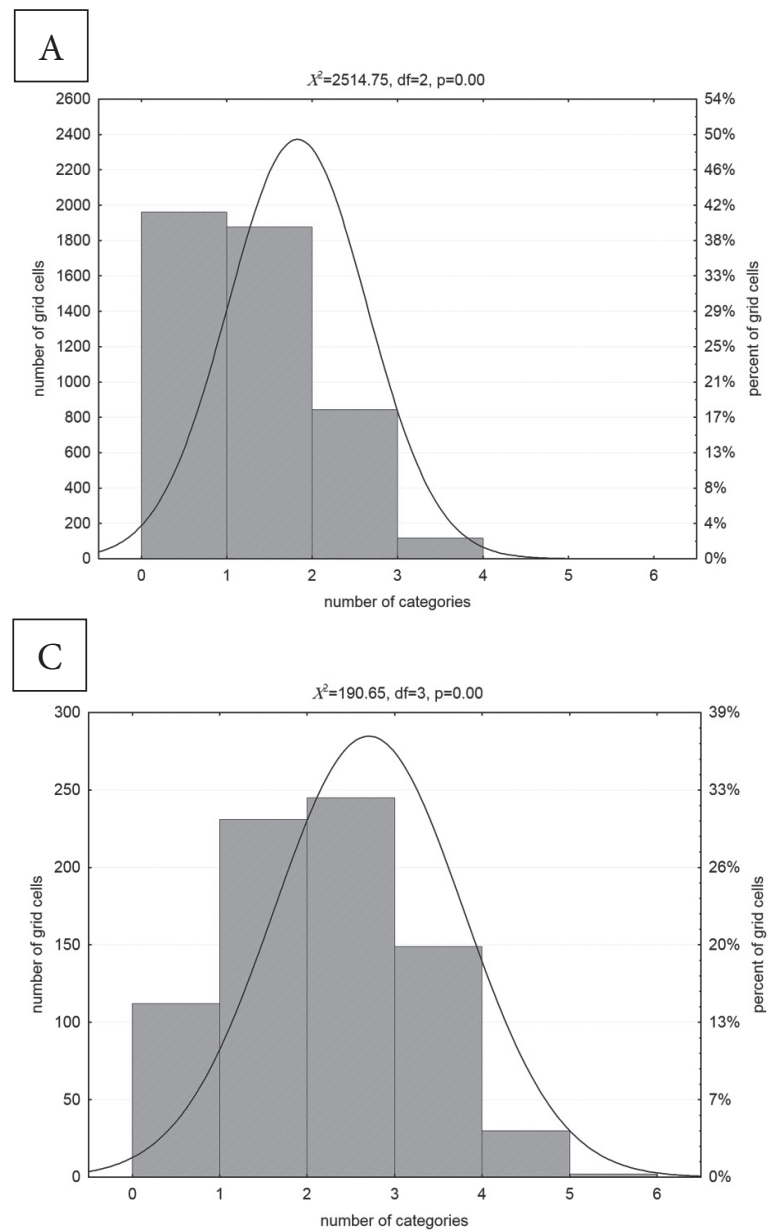

not clearly indicate which of the mentioned grids would better describe the lithostratigraphic diversity. Considering the slightly more even distribution of the category numbers in basic units (Fig. 4D), the author is in favour of the analytical grid with a size equal to $500 \mathrm{~m}$ as the most suitable for further research.
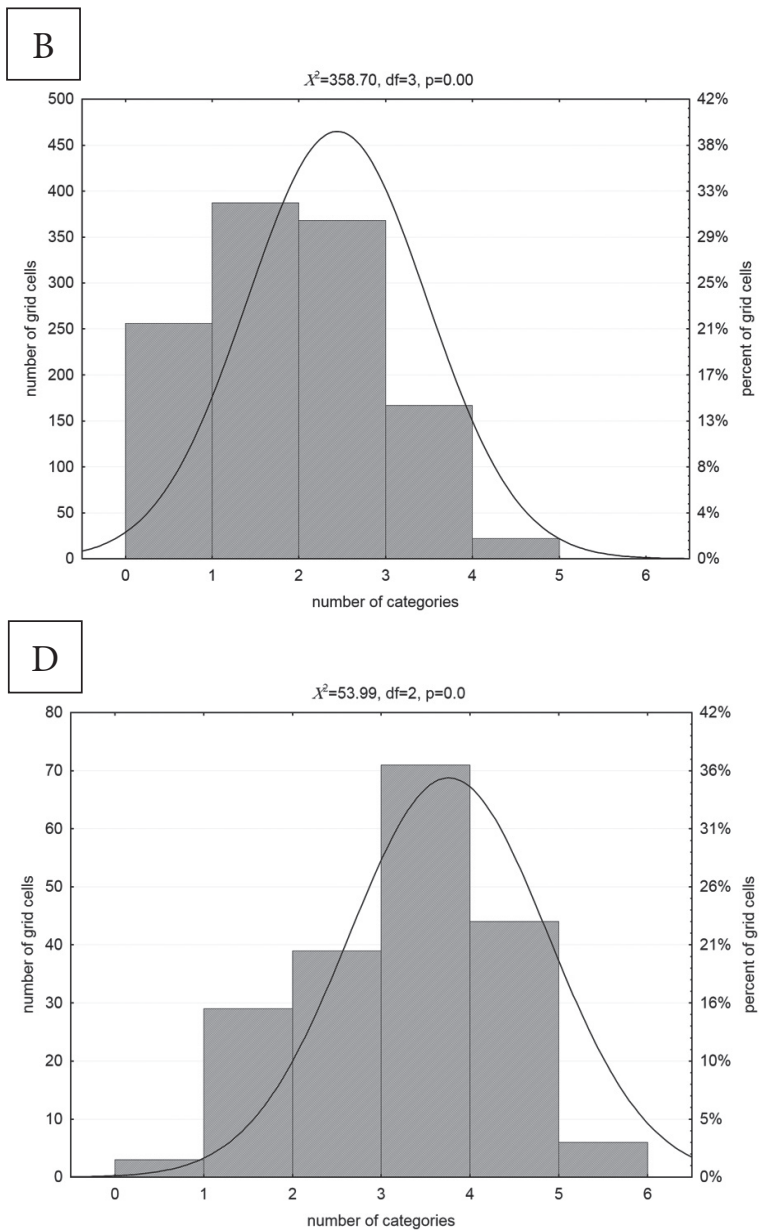

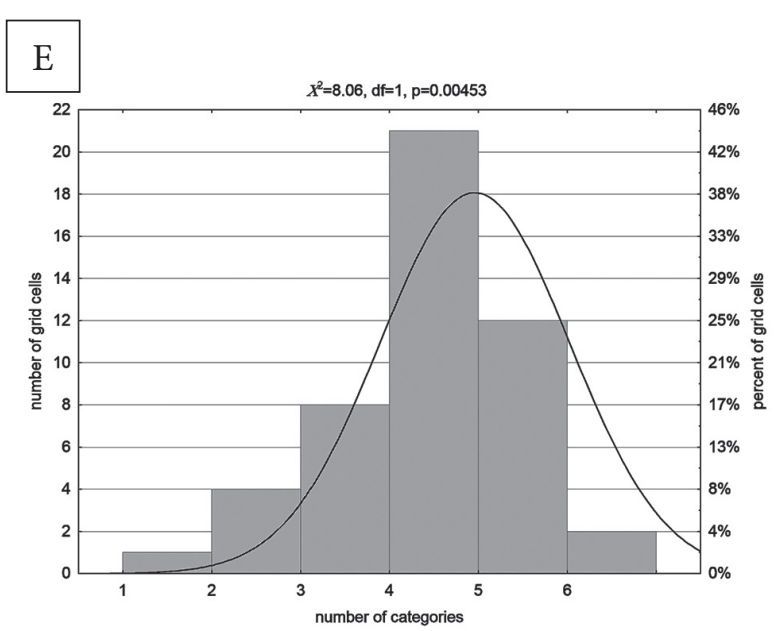

Fig. 4. Distributions of the numbers of categories of the lithostratigraphic units for the analytical grids with a basic unit size: $100 \times 100 \mathrm{~m}(\mathrm{~A}), 200 \times 200 \mathrm{~m}(\mathrm{~B}) ; 250 \times 250 \mathrm{~m}(\mathrm{C}) ; 500 \times 500 \mathrm{~m}(\mathrm{D}), 1000 \times 1000 \mathrm{~m}(\mathrm{E})$ 
To verify the results obtained, the map of the lithostratigraphic units was analysed in terms of diversity considering the surface occurrence of individual features in the basic units. All five analytical grid variants were analysed using the SHDI index. During dividing the ranges of variability of the SHDI into valuation classes, the equal interval method was used. This allows a good representation of continuous variables, and its use ensures consistency classes of the individual analysis, independently from the SHDI variability. To make the appropriate comparisons possible, factors calculated for individual basic units underwent a four-level score bonitation: no diversity and low diversity $(0-0.4)$, medium diversity $(0.4-0.8)$, large diversity $(0.8-1.2)$ and very large diversity (1.2-1.6). Its results are shown in form of cartograms (Fig. 5), basic descriptive analyses (Tab. 4) and histograms (Fig. 6).

Table 4

SHDI index variability for analytical grids with various basic unit size

\begin{tabular}{|c|c|c|c|c|c|c|c|c|c|c|c|}
\hline $\begin{array}{c}\text { Window } \\
\text { size [m] }\end{array}$ & $\begin{array}{c}\text { Number } \\
\text { of obser- } \\
\text { vations }\end{array}$ & Mean & $\begin{array}{c}\text { Me- } \\
\text { dian }\end{array}$ & Mode & $\begin{array}{c}\text { Number } \\
\text { of mode }\end{array}$ & Min & Max & $\begin{array}{c}\text { Lower } \\
\text { quartile }\end{array}$ & $\begin{array}{c}\text { Upper } \\
\text { quartile }\end{array}$ & $\begin{array}{c}\text { Skew- } \\
\text { ness }\end{array}$ & Kurtosis \\
\hline 100 & 4800 & 0.32 & 0.18 & 0 & 1961 & 0 & 1.35 & 0 & 0.64 & 0.61 & -0.98 \\
\hline 200 & 1200 & 0.51 & 0.55 & 0 & 256 & 0 & 1.41 & 0.06 & 0.83 & 0.12 & -1.19 \\
\hline 250 & 769 & 0.58 & 0.61 & 0 & 112 & 0 & 1.40 & 0.24 & 0.88 & -0.03 & -1.06 \\
\hline 500 & 192 & 0.78 & 0.83 & 0 & 3 & 0 & 1.52 & 0.44 & 1.07 & -0.24 & -1.01 \\
\hline 1000 & 48 & 0.99 & 1.15 & multiple & 1 & 0.26 & 1.56 & 0.71 & 1.26 & -0.63 & -0.74 \\
\hline
\end{tabular}

The cartogram analysis (Fig. 5) confirms the results obtained in the research on the number of lithostratigraphic unit categories in the analytical grid fields. As the basic unit size increases, the number of cells with a low diversity visibly decreases and the number of the units with a high diversity increases. This is confirmed by the statistical analyses of the SHDI index average value measures in the basic units (Tab. 4). Both the arithmetical mean values and the medians rise gradually from the grid of $100 \mathrm{~m}$ to the grid of $1000 \mathrm{~m}$.

Intervals between maximum and minimum SHDI values calculated for individual grids have similar values. Their range changes from the value of 1.3 (for the grid of $1000 \mathrm{~m}$ ) to 1.52 (for the grid of $500 \mathrm{~m})$. The grid of $1000 \mathrm{~m}(0.55)$ was characterised by the lowest value of the quartile SHDI index range, and the grid of $200 \mathrm{~m}$ by the maximum value (0.77) (Tab. 4).

The histograms developed for individual analytical grids are characterized by a variable asymmetry (Fig. 6). For grids with a basic unit size of $100 \mathrm{~m}$ and $200 \mathrm{~m}$ they are visibly asymmetrical to the right, while they were asymmetrical to the left for the grid with a basic unit size of $1000 \mathrm{~m}$. Only the grids with a basic unit size of $250 \mathrm{~m}$ and $500 \mathrm{~m}$ have a distribution similar to the symmetrical one. The asymmetry factor closes to ' 0 ', indicating distribution symmetry, is found for the grid with the basic unit size of $250 \mathrm{~m}$ (Tab. 3, Fig. 6C). The negative kurtosis values, typical for all analysed grids (Tab. 4) indicate a flat (platocurtic) nature of the distributions in relation to the normal distribution.

Cartograms developed with the grids of the size of 100-250 m (Fig. 5A-C) show a large rate of the basic units with only one category of the studied feature (number of mode: $40 \%, 21 \%$ and $14 \%$, respectively; Tab. 4). The analysis of the SHDI index variability yields interesting results in the two other cases: when grids with the basic unit size of $500 \mathrm{~m}$ and of $1000 \mathrm{~m}$ were used. In both cases, the SHDI value from the modal interval was observed for about $35 \%$ of all basic units (Tab. 4). The SHDI index variability distribution for the grid with the basic unit size of $1000 \mathrm{~m}$ is, however, clearly negatively asymmetrical, and the modal interval is present in the extremely right part of the chart (Fig. 6E). 

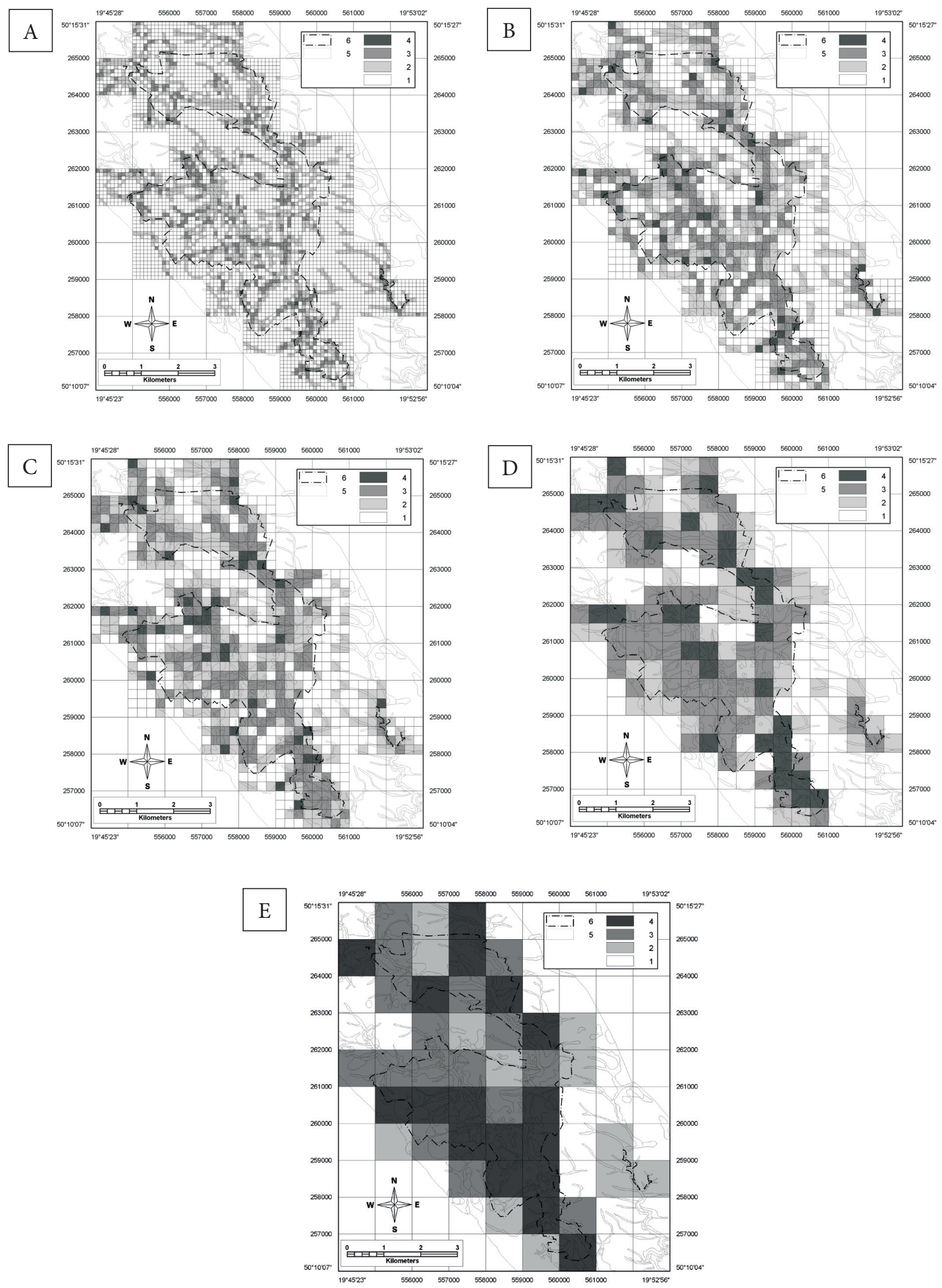

Fig. 5. Cartograms of the SHDI indexes for lithostratigraphic unit diversity for basic unit sizes of: $100 \times 100 \mathrm{~m}(\mathrm{~A}), 200 \times 200 \mathrm{~m}$ (B), $250 \times 250 m(C), 500 \times 500 m(D), 1000 \times 1000 m(E)$, SHDI: 1 - 0-0.4; 2 - 0.4-0.8; 3-0.8-1.2; 4- 1.2-1.6; 5 - lithostratigraphic units; 6 - the ONP boundaries 
It seems that the cartogram prepared for this grid (Fig. 5E) is characterised by the over-presentation of the basic units with the maximum diversity.
The disclosed result indicates that the analytical grid with the size of $500 \mathrm{~m}$ is suitable for the described case.
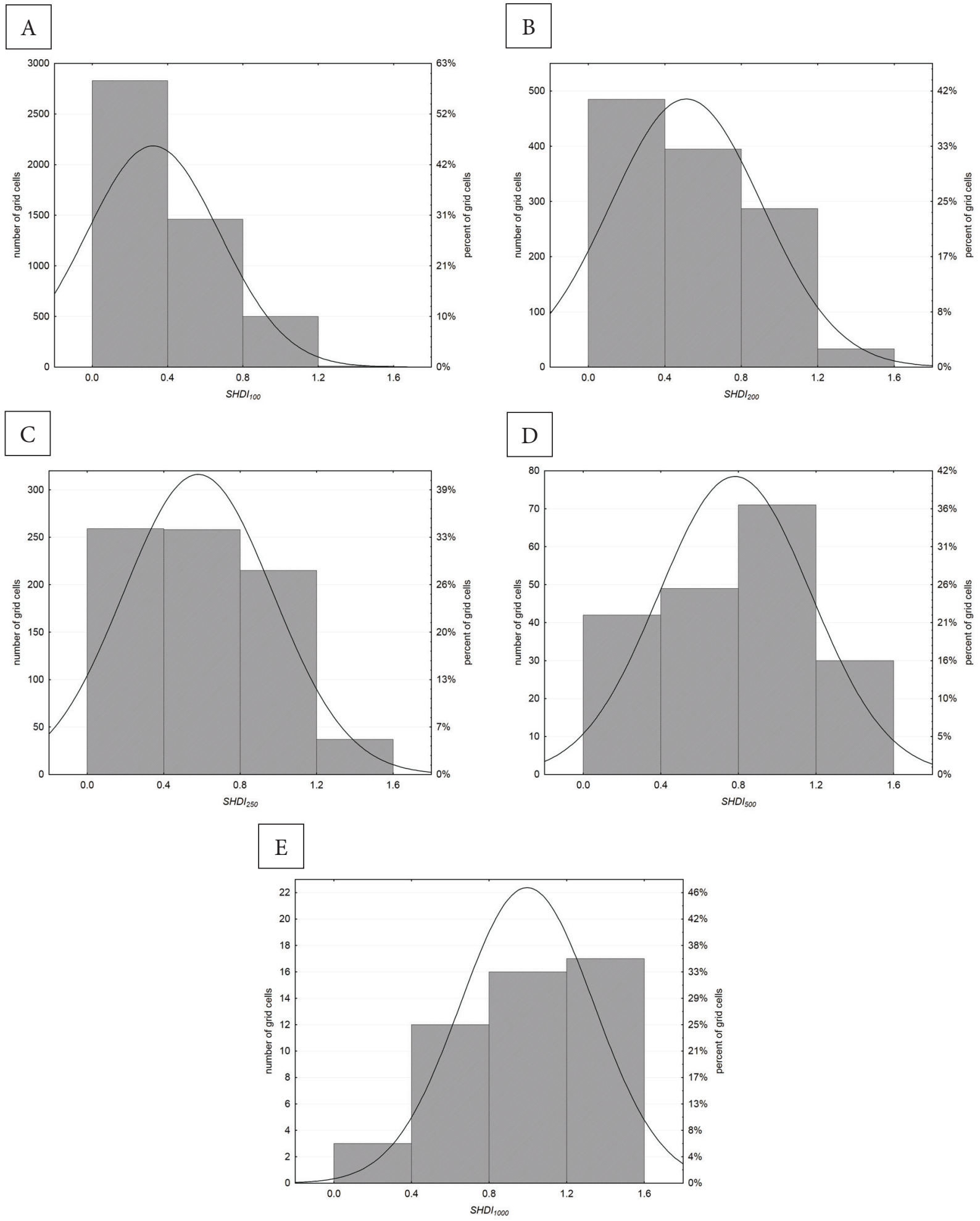

Fig. 6. Distributions of the SHDI indexes of the lithostratigraphic unit variability for the analytical grids of the basic unit size of: $100 \times 100 m(A), 200 \times 200 m(B), 250 \times 250 m(C), 500 \times 500 m(D), 1000 \times 1000 m(E)$ 


\section{CONCLUSIONS}

The article describes the procedure of empirical selection of a basic unit size in the medium-scale landscape and goediversity analyses employing a regular analytical grid with square cells.

Both too small and too large a basic unit size has a negative effect on the conducted analyses, resulting in a loss of a significant part of information and preventing the correct interpretation of results.

The research conducted proves that the simple empirical approximation of the optimal basic unit size is possible. It should be stated, however, that this is not an easy task and, in many cases, may yield dubious results. The data analysis conducted with grids with the optimal basic unit size should be characterized by a high informative value. Such grids facilitate the analysis of data and results obtained on its basis, as well as drawing correct conclusions. The analytical grids have a large informative capacity when they contribute relatively the largest amount of information for the previously established study scale. In practice, the large informative capacity depends on distributions of the number of the studied feature categories in the analytical grid basic units.

Empirical studies of the ONP area showed that for low cells sizes (100-250 m), the lithostratigraphic variability in the basic units showed a positive skew and a high number of cells with only one category of examined features (respectively: $40 \%, 21 \%$, and $14 \%$ ). Interestingly, the results show an analysis of the SHDI index variability in the two other cases, when using the grids with cells with sizes of 500 $\mathrm{m}$ and $1000 \mathrm{~m}$. In both of these situations, approximately $35 \%$ of all basic units showed SHDI values from the modal range. However, distribution of the SHDI for the grid with the cell size of $1000 \mathrm{~m}$ is clearly negatively asymmetric and the modal class is in the far right of the graph. It appears that the cartogram drawn for this grid has an overrepresentation of the basic units with maximum values of the geodiversity. As a result, the optimal basic unit size is $500 \mathrm{~m}$ and this is indicated by the symmetrical distribution of the approximated variable and the clearly defined modal class.

Conditions for the selection of the grid with the optimal cells size should be: a small number of basic units with the outlaying category numbers and possibly wide ranges for non-outlying minimum and maximum values, and as well as for the quartile ranges. The distributions of the category numbers in the basic units should be characterized by low asymmetry levels and mesokurtisis in relation to the normal distribution.

The results shown prove that the basic unit size has a fundamental effect on the quality of the evaluation of feature diversity and it should always depend on the number of categories, the spatial variability of the studied feature, the input data accuracy, as well as the aim and the scale of the target results processing.

Cartograms based on grids with basic units which are too small are characterized by the overestimation of a studied area with no diversity. When too large basic units are applied, we see the reverse situation. In this case, the cartograms developed will be characterised by a substantial overestimation of the area with maximum diversity.

In the future, research on the discussed problem should focus on simplifying the method of the selection of the optimal basic unit size. It seems that the right direction would be to examine the correlations between the abundance of categories, the size of the study area and the minimum and maximum size of the patches.

The method used was designed to optimalize the basic unit size in geodiversity analysis yet its usefulness is much wider. It can be applied in any studies whose purpose is to evaluate the natural environment.

The execution of this work was possible due to the financial support provided by the Polish Scientific Research Committee, as part of the statutory works No. 11.11.140.173.

\section{REFERENCES}

Abe T., Levin S.A. \& Higashi M. (eds.), 1997. Biodiversity: an ecological perspective. Springer, New York.

Alexandrowicz S.W., Alexandrowicz Z. 2003. Pattern of karst landscape of the Cracow Upland (South Poland). Acta Carsologica, 32(1), 39-56.

Burnett M.R., August, P.V., Brown J.H., Jr., Killingbeck K.T., 1998. The influence of geomorphological heterogeneity on biodiversity I. A patch-scale perspective. Conservation Biology, 12, 363-370. 
Buyantuyev A. \& Wu J., 2007. Effects of thematic resolution on landscape pattern analysis. Landscape Ecology, 22, 7-13.

Corry R.C. \& Lafortezza R., 2007. Sensitivity of landscape measurements to changing grain size for fine-scale design and management. Landscape and Ecological Engineering, 3, 47-53.

Dixon G., 1996. Geoconservation: An International Review and Strategy for Tasmania. Occasional Paper, 35, Parks $\&$ Wildlife Service, Tasmania.

Eberhard R. (ed.), 1997. Pattern \& Process: Towards a Regional Approach to National Estate Assessment of Geodiversity. Australian Heritage Commission, Canberra.

Eiden G., Kayadjanian M. \& Vidal C., 2000. Quantifying Landscape Structures: spatial and temporal dimensions, in From land cover to landscape diversity in the European Union. Report of the European Commission, [on-line:] http://ec.europa.eu/agriculture/publi/reports /corine2000.pdf [access: 19.10.2016].

Forman R.T.T., 1997. Land mozaics, the ecology of landscapes and regions. Cambridge University Press, Cambridge New York.

Forman R.T.T., \& Godron M., 1986. Landscape Ecology. Wiley and Sons, New York.

Gaston K.J. (ed.), 1996. Biodiversity: a biology of numbers and difference. Blackwell Science, Oxford.

Gehlke C.E. \& Biehl K., 1934. Certain effects of grouping upon the size of the correlation coefficient in census tract material. Journal of the American Statistical Association, 29, 169-170.

Gergel S.E., \& Turner M.G. (eds.), 2002. Learning Landscape Ecology: A Practical Guide to Concepts and Techniques. Springer-Verlag, New York - Berlin - Heidelberg.

Gray M., 2004. Geodiversity - valuing and conserving abiotic nature. John Wiley \& Sons, The Atrium, Southern Gate, Chichester.

Greig-Smith P., 1983. Quantitative plant ecology. University of California Press, Berkeley.

Hengl T., 2006. Finding the right pixel size. Computers \& Geosciences, 32, 1283-1298.

Hjort J. \& Luoto M., 2010. Geodiversity of high-latitude landscapes in northern Finland. Geomorphology, 115, 109-116.

Kot R., 2014. The point bonitation method for evaluating geodiversity: A guide with examples (Polish Lowland). Geografiska Annaler: Series A, Physical Geography, 97, 375-393, doi: 10.1111/geoa.12079.

Kot R. \& Leśniak K., 2006. Ocena georóżnorodności za pomocą miar krajobrazowych - podstawowe trudności metodyczne. Przeglad Geograficzny, 78, 25-45.

Kozieł Z., 1993. Barwny kartogram złożony jako metoda badań i prezentacji wybranych zjawisk geograficznych. Uniwersytet Mikołaja Kopernika, Toruń.

Kozłowski S., 2004. Geodiversity. The concept and scope of geodiversity. Przeglad Geologiczny, 52, 2, 833-837.

Krummel J.R., Gardner R.H., Sugihara G., O’Neill R.V. \& Coleman P.R., 1987. Landscape patterns in a disturbed environment. Oikos, 48, 321-324.

Legendre P. \& Fortin M.J., 1989. Spatial pattern and ecological analysis. Vegetatio, 80, 107-138.

Leser H. \& Nagel P., 1998. Landscape diversity - a holistic approach. [in:] Barthlott W. \& Winiger M. (eds.), Biodiversity. a challenge for development research and policy, Springer-Verlag, Berlin, 129-143.
Matheron G., 1963. Principles of geostatistics. Economic Geology, 58, 1246-1266.

Meisel J.E. \& Turner M.G., 1998. Scale detection in real and artificial landscapes using semivariance analysis. Landscape Ecology, 13, 347-362.

Miśkiewicz K., 2009. Geodiversity research problems in geotourism. Geoturystyka Geotourism, 16/17, 3-12.

McArthur R., Wilson E.O., 1968. The theory of island biogeography. Princeton.

McGarigal K. \& Marks B.J., 1995. FRAGSTATS: spatial pattern analysis program for quantifying landscape structure. USDA Forest Service. Technical Reports, PNWGTR-351, Portland.

McGarigal K., Cushman S.A. \& Ene E., 2012. FRAGSTATS v4: Spatial Pattern Analysis Program for Categorical and Continuous Maps. Computer software program produced by the authors at the University of Massachusetts, Amherst. [on-line:] http://www.umass.edu/landeco/ research/fragstats/fragstats.html [access: 19.10.2016].

Nichols F., Killingbeck K.T. \& August P.V., 1998. The influence of geomorphological heterogeneity on biodiversity. Conservation Biology, 12(2), 371-379.

Openshaw S., 1984. The modifiable areal unit problem. CATMOG 38. GeoBooks, Norwich, England.

Örsi A., 2011. Quantifying the geodiversity of a study area in the Great Hungarian Plain. Journal of Environmental Geography, 4, 1-4, 19-22.

Pereira D.I., Pereira P., Brilha J. \& Santos L., 2013. Geodiversity assessment of Paraná State (Brazil): An innovative approach. Environmental Management, 52, 3, 541-552.

Plotnick R.E., Gardner R.H. \& O'Neill R.V., 1993. Lacunarity indices as measures of landscape texture. Landscape Ecology, 8, 201-211.

Plotnick R.E., Gardner R.H., Hargrove W.W., Prestegaard K. \& Perlmutter M., 1996. Lacunarity analysis: a general technique for the analysis of spatial patterns. Physical Review, 53, 1-8.

Płonczyński J., 2001. Mapa geologiczna Ojcowskiego Parku Narodowego wraz z otulina. Badania naukowe w poŁudniowej części Wyżyny Krakowsko-Częstochowskiej. [in:] Partyka J. (red.), Badania naukowe w południowej części Wyżyny Krakowsko-Częstochowskiej: materiały konferencyjne, referaty, postery, sesje terenowe, Ojców 10-11 maja 2001 r., Ojcowski Park Narodowy, Ojców, $73-76$.

Prosser C.D., 2002. Terms of endearment. Earth Heritage, 17, 13-14.

Quinta-Nova L.C. \& Cabaceira S., 2014. The importance of land use metrics in the design of landscape units. The study case of Centro region of Portugal. [in:] IALE-Europe Thematic Workshop 2014, Advances in Spatial Typologies: How to move from concepts to practice? 4-5 July 2014, Instituto Superior Técnico, Lisbon, [on-line] http:// repositorio.ipcb.pt/bitstream/10400.11/2433/1/Poster Workshop_IALE.pdf].

Radeloff V.C., Miller T.F., He H.S. \& Mladenoff D.J., 2000. Periodicity in spatial data and geostatistical models: autocorrelation between patches. Ecography, 23, 81-91.

Rossi R.E., Mulla D.J., Journel A.G. \& Franz E.H., 1992. Geostatistical tools for modeling and interpreting ecological dependence. Ecological Monographs, 62, 277-314. 
Serrano E. \& Ruiz-Flaño P., 2007a. Geodiversidad: concepto, evaluación y aplicación territorial. El caso de Tiermes Caracena (Soria). Boletín de la Asociación de Geógrafos Españoles, 45, 79-98.

Serrano E. \& Ruiz-Flaño P., 2007b. Geodiversity: a theoretical and applied concept. Geographica Helvetica, 62(3), 140147.

Shannon C.E. \& Weaver W., 1949. The mathematical theory of communication. University of Illinois Press, Urbana.

Sharples Ch., 1993. A Methodology for the Identification of Significant Landforms and Geological Sites for Geoconservation Purposes. Forestry Commission, Tasmania.

Silva J.P., Pereira D.I., Aguiar A.M. \& Rodrigues C., 2013. Geodiversity assessment of the Xingu drainage basin. Journal of Maps, 9, 2, 254-262.

Stanley M., 2001. Welcome to the 21st century. Geodiversity Update, $1,1$.
Stanley M., 2003. Geodiversity: our foundation. Geology Today, 19, 104-107.

Suchożebrski J., 2004. The size of the basic unit in geographical analysis. Miscallanea Geographica, 11, 151-160.

Šímová P. \& Gdulová K., 2011. Changes in landscape heterogenity described by Shannon diversity index - Czech Republic. Faculty of Environmental Sciences, Department of Applied Geoinformatics and Spatial Planning, Česká zemědělská univerzita v Praze, Praha.

Turner M.G., O’Neill R.V., Gardner R.H. \& Milne B.T., 1989. Effects of changing spatial scale on the analysis of landscape pattern. Landscape Ecology, 3, 3-4, 153-162.

$\mathrm{Wu}$ J., 2004. Effects of changing scale on landscape pattern analysis: scaling relations. Landscape Ecology, 19, 2, 125-138. Zonneveld I.S., 1995. Land ecology: an introduction to landscape ecology as a base for land evaluation, land management and conservation. SPB Academic Publishing, Amsterdam. 